Article

\title{
Business Model as a Base for Building Firms' Competitiveness
}

\author{
Tihana Koprivnjak *(1) and Sunčica Oberman Peterka \\ Faculty of Economics in Osijek, Josip Juraj Strossmayer University of Osijek, 31000 Osijek, Croatia; \\ suncica.oberman.peterka@efos.hr \\ * Correspondence: tihana.koprivnjak@efos.hr
}

Received: 8 October 2020; Accepted: 7 November 2020; Published: 9 November 2020

check for updates

\begin{abstract}
Designing and creating a business model is crucial for a successful firm's operation in today's market in a complex and changing environment. A business model is the factor that differentiates one firm from another-it defines the distinctions of the firm, how the firm deals with the competition, the firms' partnerships, and customer relations. This paper explores the role of the business model in the creation of sustainable competitive advantage. The empirical part of the paper presents the business model of three small companies from the Information and Communications Technology (ICT) industry in Croatia using the Business Model Canvas. Additionally, business model components were also analyzed using a framework for evaluating a business model. The results of the analysis point to a few crucial components of the business model, on which small ICT firms in Croatia build their competitive advantage by creating significant distinctions of those components. These distinctions are essential for their longevity and sustainability.
\end{abstract}

Keywords: business model; competitive advantage; ICT industry; SMEs

\section{Introduction}

More and more investors and other stakeholders are asking companies to explain their business using the business model concept [1]. The business model has become a commonly used tool for defining and illustrating all aspects of a firm. It is primarily used as the basis for defining the competitive advantage of each firm, talks about how the firm appears on the market, deals the competitors, and defines partnership relations as well as relationships with customers. In order for a firm to operate successfully in today's market, in an extremely complex and changing environment, it is crucial to design and create a business model that will ensure a competitive advantage for the company. The business model is like a blueprint for a strategy implementation through organizational structures, processes, and systems [2]. A deficient business model can be the cause of a firm's failure, even in a situation of properly identified market opportunities with adequate resources and talented entrepreneurs who carry the business [3]. Even firms that meet the same consumer need and have a similar marketing strategy for their products, may have completely different business models [4].

Business models have become the focus of attention of many researchers and practitioners around the world. Significant interest in business models has arisen due to several important reasons: the emergence of the Internet, the growth of new markets, interest in "bottom-up" problems, and the growth of industries and organizations that depend on post-industrial technologies [4]. Additionally, it is evident that with the advancement of technology, business models have gained in importance, and business models are no longer seen only as an operational plan for creating an appropriate information system, but as an integrated presentation of the company organization, which contributes to the success of the management in the decision-making process [5]. Nowadays, companies need to think about different building blocks of their business, and even about new enterprise architecture to be able 
to incorporate new information technologies with business strategies and components [6]. Indeed, digitization and accessibility of the Internet have given firms the opportunity to fundamentally change the way they organize their relationships and engage in economic activities, both within the company and industry and outside these frameworks [4,7]. The business model concept gives an overview of the entire business and the philosophy of a firm. The role of the business model is to provide a set of general descriptors of how a firm is organized in order to create and distribute value in a profitable manner [8].

By combining components of the business model, the firm creates a unique way of doing business that should lead to competitive advantage, which allows the firm to differentiate itself from the competition and achieve long-term and sustainable success in the market. A good business model contains the overall business logic and the answers to all important questions about the business and relationships within the firm as well as with stakeholders outside the firm. Therefore, the business model can be used as an important tool for analyzing and understanding the business of a firm. However, the business model is highly dependent on the industry of the firm. Industry characteristics and trends surely have a high impact on the firm's business model and competitive advantage. Deeper understanding of the firm's business model in the specific industry could provide relevant knowledge that affects the success of those businesses. Finally, small and medium enterprises (SMEs) are a crucial segment of every economy. In the European Union, $99.8 \%$ of all businesses are small and medium enterprises, which account for $66.6 \%$ of the employment [9]. SMEs have limited resources, face many challenges in everyday business, and often struggle with sustainability and growth. Hence, the aim of this paper is to show the importance of a firm's business model in creating sustainable competitive advantage within SMEs in the Information and Communication Technology (ICT) industry. This study seeks to contribute in defining the similarities and differences of the business model components and characteristics by using the Business Model Canvas as a tool for reviewing, interpreting, and presenting a firm's business, with a focus on the ICT sector as a propulsive and prominent sector of the economy, and small enterprises as a vast building block of every country's economy.

This paper provides an overview of the relevant literature from the field of business model research. The section on theoretical perspectives of business models gives an overview of the literature on the business models, its meaning, ways, and approaches of business model creation and innovation. Subsequently, the methodology of the research is explained as the rationale for choosing the qualitative research for this paper. Results of the research and discussion focuses on the role of the business model in creating competitive advantage on the examples of three firms from the ICT sector (information and communication technologies). The paper provides theoretical and managerial contribution as well as suggestions for future research.

\section{Business Model-Theoretical Perspective}

Given the relatively recent interest of researchers in the issue of business models, there are still various definitions of the business model. Business model can be defined according to the three perspectives: strategic, operational, and economic [1]. In its essence, the business model is concerned with the economic settings of a business venture (i.e., the way of generating revenues). After that, the focus shifts to operational aspects: process structure, infrastructure, and administration. Finally, at the strategic level, the business model shows the direction of the business and market positioning, and includes stakeholder interests as well as opportunities for growth. A similar view is that a business model is a firm's plan to create value, fight competition, use resources, structure relationships with partners and customers, and generate profit [10]. The business model defines how the enterprise creates and delivers value to customers and then converts the payments received into profit [2,11]. Moreover, the business model is a simplified and aggregated representation of all the relevant activities of a company, which describes how a company, by creating additional value, creates marketable products or services. The business model represents a conceptual framework to organize the process of value creation of a firm, which can help to achieve profitability [5]. Finally, another view is that business 
model definition differentiates according to the discipline that studies them [12]. In the field of strategic management, business models are defined as activities, strategies, and actions that create, deliver, and ensure value for the firm. In the field of entrepreneurship, a business model is a set of decisions that an entrepreneur must make in order to exploit a business opportunity. In the study of marketing, the business model is viewed from a network perspective, looking primarily at relationships with partners and other stakeholders, which are essential for value creation. In organizational studies, the focus is on the organization of activities and the basic elements of the business model, which are necessary for the functioning of the organization. Finally, scientists who focus on studying practice, view the business model as a tool that can monitor the company strategies and tactics, and changes in them.

The business model of a firm provides an overview of the firm's entire business and the relationships it creates. The importance of setting up a clear business model is reflected in the fact that it allows an assessment of all elements of business and their sustainability, and it is possible to clearly read the relationship toward the firm's stakeholders.

\subsection{Elements of the Business Model}

As there are various definitions of the business model, the authors also list various combinations of the components of the business model. Table 1 presents different views on the business model components.

Table 1. Overview of the business model components.

\begin{tabular}{|c|c|}
\hline Authors & Business Model Components \\
\hline Morris et al. (2006) [1] & $\begin{array}{l}\text { 1. Value offering-how does the firm create value } \\
\text { 2. Market-for whom does the firm create value } \\
\text { 3. Internal capabilities-what is the firm's source of capability/advantage } \\
\text { 4. Economic factors-how does the firm make money } \\
\text { 5. Competitive strategy-how does the firm differentiate itself } \\
\text { 6. Personal and investment factors-what are the firms' ambitions (in } \\
\text { terms of time, scope and size }\end{array}$ \\
\hline $\begin{array}{l}\text { Johnson et al. (2008) } \\
\text { [13] }\end{array}$ & $\begin{array}{l}\text { 1. Customer value proposition-solving a problem that a customer has, } \\
\text { which needs a solution. } \\
\text { 2. Profit formula-how the firm creates value for itself while providing } \\
\text { value for the customer, and it consists of several parts: revenue model, } \\
\text { cost structure, margin model and resource velocity. } \\
\text { 3. Key resource-those resources that are indispensable in creating } \\
\text { value for the customer and for the company. } \\
\text { Key processes-operational and managerial processes that allow } \\
\text { companies to create and deliver value in a way they can successfully } \\
\text { repeat and increase in scale. }\end{array}$ \\
\hline $\begin{array}{c}\text { Shi and Manning (2009) } \\
{[14]}\end{array}$ & $\begin{array}{l}\text { 1. The exchange sub-model—the added value that a firm offers to other } \\
\text { actors in a market. } \\
\text { 2. The organizational sub-model—all the roles and responsibilities, } \\
\text { activities and business processes, which allow the flow of products, } \\
\text { information and money to achieve the exchange between the firm and } \\
\text { its partners. } \\
\text { 3. The resource sub-model—all the resources that the firm mobilizes } \\
\text { 4. The financial sub-model—minimizing or maximizing individual } \\
\text { items, so that the firm ultimately achieves a positive result. }\end{array}$ \\
\hline
\end{tabular}


Table 1. Cont.

\begin{tabular}{|c|c|}
\hline Authors & Business Model Components \\
\hline $\begin{array}{l}\text { Barringer and Ireland } \\
\text { (2010) [10] }\end{array}$ & $\begin{array}{l}\text { 1. Core strategy-how the firm plans to compete with its competitors. } \\
\text { 2. Strategic resources-how the firm procures and uses resources } \\
\text { 3. Partnership network-all suppliers and other partners that the firm } \\
\text { needs to achieve its goals and on which it relies to perform certain } \\
\text { key roles } \\
\text { 4. Customer relationships - the way how firm interacts with customers }\end{array}$ \\
\hline Wirtz et al. (2016) [5] & $\begin{array}{ll}\text { 1. } & \text { Strategic components } \\
\text { 2. } & \text { Customer and market components } \\
\text { 3. } & \text { Value creation components }\end{array}$ \\
\hline $\begin{array}{l}\text { Osterwalder and } \\
\text { Pigneur (2014) [2] }\end{array}$ & $\begin{array}{ll}\text { 1. } & \text { Customer segments, } \\
\text { 2. } & \text { Value propositions, } \\
\text { 3. } & \text { Channels, } \\
\text { 4. } & \text { Customer relationships, } \\
\text { 5. } & \text { Revenue streams, } \\
\text { 6. } & \text { Key resources, } \\
\text { 7. } & \text { Key activities, } \\
\text { 8. } & \text { Key partnerships, } \\
\text { 9. } & \text { Cost structure }\end{array}$ \\
\hline
\end{tabular}

As can be seen, different authors have different constructs of business models. They differ in the number of elements and somewhat in their explanation. However, the main logic behind all the components is that the business model has to include all relevant aspects of the business: strategy, finance, product/service, market, and resources. The business model is a framework that has interlocking and interrelated elements that provide a holistic overview of the business that will help business to define and understand its competitive advantage.

\subsection{Creating and Innovating a Business Model}

The business model is created based on thee proven potential of the product or service and can serve as the basis for a sustainable business [10]. Creating a business model is different for each venture and each organization (profit-oriented, socially-oriented, artistic, scientific, etc.), and due to the fact that starting a business venture is triggered by different motivations, the processes of designing, operationalization, outcomes, and changes of the business model are different [15]. All relevant factors in creating the value of the final product/service must be taken into account when creating a business model, since the business model shows the logic of creating and delivering value to the customer, and provides the necessary information about this process [11]. It must start from the decision on the technologies to be used, the features of the products/services it will offer, and the benefits that these products/services will provide to customers [11]. Furthermore, it is important to identify the target market and how the firm will generate revenue, and to design mechanisms that will monitor and record the value achieved. From this process, it can be concluded that the business model contains the organizational and financial architecture of the firm and it shows how the firm creates value for the customer, collects payments, and converts payments to profit. The business model can be designed through a process that consists of five phases:

1. Mobilization,

2. Understanding,

3. Designing, 
4. Implementation, and

5. Managing [2].

Mobilization involves the preparation for designing the business model. In this phase, the project objectives are determined, preliminary ideas are tested, the project is planned, and a team is assembled to understand the aims of the research and to analyze the elements needed to design a business model. Here, it is important to understand the context in which the business model will be developed, which means that all important elements of the business such as customers, technology, and environment must be examined. The third phase, designing, seeks to convert ideas from previous phases into business models that will be explored and tested, and select the one that is the best solution. The goal of the implementation phase is to implement the business model prototype into practice, and in order to implement it successfully, it is essential to ensure the participation of all necessary participants and constant communication in the company. Managing is the last phase, which involves constantly monitoring the business model and scanning the environment to improve or adapt the business model to the reactions that have been identified in the market.

It is important to understand that business models have their life cycle [15]. The phrase life cycle is known from the concept of the product life cycle and company life cycle, and these authors apply it to the process of creating and evolving a business model. It is a common belief that all business models need to change over time. Business model innovations have reshaped entire industries and redistributed billions of dollars [13]. Every organization needs to carefully review whether the time is right to revise its business model, either to pursue new opportunities in its industry or to respond to threats [16]. Business model innovation is the subject of numerous scientific studies for two main reasons [4]. The first reason is that firms commercialize innovative ideas and technologies through their business models. The second reason lies in the fact that business models are a new subject of innovation in firms, which is complementary to the previous process, product, and organizational innovation, and involves new forms of cooperation and partnership. Business model innovation is a process that changes the firm's current business model and creates a new combination of elements, which will help the firm to retain the existing or create a better position in the market [4]. What many definitions of business model innovation have in common is the emphasis on completely replacing the existing business model with a new one (i.e., a complete reversal in thinking and doing business) [17-19]. Firms constantly innovate their business models, thus trying to create added value and change the standard ways in which products and services are produced and sold in their industry [10]. Today, the so-called disruptive business models, which completely change certain industries or create new ones, are appearing with increasing frequency. Disruption is the creation of a business idea that disrupts and changes market conventions and enables the achievement of the new vision of the firm [20]. Disruption creates a foundation for business model innovation. The main goal of business model innovation is the generation of a sustainable competitive advantage $[5,19]$. Business model innovation can be seen as a result of one of the following company objectives:

1. to satisfy existing but unanswered market needs,

2. to bring new technologies, products, or services to market,

3. to improve an existing market, or

4. to create an entirely new market [2].

Furthermore, two types of innovation can be distinguished: innovation within the business model, where changes occur in the design and functioning of the elements of the business model, and innovation of the entire business model, which involves questioning and changing fundamental business ideas [15]. In this context, the authors talk about the drivers of innovation (internal and external) as well as the nature of innovation (proactive and reactive). Changes take place in response to internal or external circumstances relevant to the firm and its business model. Changes that are proactive take place because of the initiative of the entrepreneur, while reactive changes occur because 
the firm must respond to the new circumstances that affect the functioning or effectiveness of the business model.

In order to create or maintain a competitive advantage, it is necessary to critically examine the need for business model innovation due to internal or external changes that have occurred over time [19]. Business models have to change and evolve to be sustainable [15] and business model innovation is extremely important for firm growth and longevity [21]. However, a firm should be aware that business model innovation is unpredictable and time-consuming, and it is necessary to solve numerous ambiguities and uncertainties, analyze alternatives, and find a good solution [2]. A major obstacle to business model innovation stems from the fact that only a few companies understand their existing business model well enough, the premise behind its development, its strengths, and limitations, and therefore cannot know when a new business model is needed to ensure business success [13]. Lately, research suggests that firms should consider business model experimentation as a way of overcoming organizational inertia, gaining new knowledge and boosting innovation [22]. The newest focus of the research of business model innovation is oriented toward sustainable business model innovation, where companies must include environmental and societal elements in their new business model [22-25]. Finally, it can be concluded that creating a new business model, which is neither new nor disruptive to the industry or market in which the firm operates, is a complete waste of time and money [13].

\subsection{From Business Model to Competitive Advantage}

Although there is still debate about the precise definition of the business model term, and whether it is a prospective field of research or extension of strategy research [26], the business model is surely a tool that can provide better understanding of how companies conduct their business, what their focus is in creating sustainable competitive advantage and how they are changing in today's turbulent era. A model is a simplified abstraction of a real situation; it is a structure that gives meaning to something, and therefore it can be said that by creating a business model, an entrepreneur wants to show key aspects of a sustainable business venture [1]. A business model is a model, meaning that it has an embedded set of cause-effect relationships [27]. By understanding the business model of a firm, we can understand what are the relevant and crucial elements needed to obtain success.

Previous research has shown that the strategic awareness of the firm implies profound understanding of the business model and its components. Competitive strategy of the firm is based on the differentiation from the competition, which is grounded in the deliberate choice of different sets of activities in order to be able to deliver a unique value mix [28]. That choice to be different from the competition requires conscious and continuous work on creating and sustaining competitive advantage. Comprehension of the current business model and business model innovation are the basis for the development of lasting competitive advantage.

As has been stated, the aim of this paper was to show the importance of a firm's business model in creating sustainable competitive advantage within SMEs in the ICT industry. Therefore, the specific research questions this research seeks to answer, are as follows:

1. How do small ICT firms create their business models?

2. What are the crucial elements of the business model of the small ICT firms on which the firms base their sustainable competitive advantage?

\section{Materials and Methods}

This paper was based on qualitative research. Qualitative research is defined as multi-paradigmatic and multi-method oriented research including a naturalistic and interpretative approach to the subject of research [29]. Qualitative research aims to interpret and explain something to ensure a better understanding of a particular problem or phenomenon [30]. Qualitative research is rooted in interpretivism as a research philosophy, and the focus is on narrative stories, perceptions, and interpretations. Therefore, derived cognitions and views are considered to be a significant contribution [31]. This approach does not seek to test and prove hypothesis, it seeks to understand 
and explore using an inductive approach to data analysis [32]. Generalizability is not the aim of the research, rather the purpose is found in the applicability of the findings through understanding the case and the context. This research will use the case study method. "A case study is an intensive study of a specific unit or system that has the characteristics of an entity" [29]. When there are multiple case studies in the research, a cross-case analysis requires a comparison of cases in search of similarities and differences between them and in relation to theory [30].

A deeper understanding provided by qualitative research and knowledge gained from specific case studies are the main reasons that such research is appropriate for this paper. By analyzing the business models of selected firms, this paper will try to understand their business and explain the sustainability of their competitive advantage.

\subsection{Defining the Sample}

Qualitative sampling is very specific process, and choosing the cases is an important step of the research process. There are some key principles of case selection that needs to be acknowledged:

- sample is not selected based on statistical probability, but on other theoretical or purposive sampling criteria,

- samples are small, but studied intensively,

- selection of the samples is sequential,

- sample selection is conceptually driven,

- there needs to be rationale about the case selection, and

- qualitative samples provide analytic generalizations, but not statistic generalization [33].

In order to select cases, purposive sampling was used. Purposive sampling implies that the researcher recognizes and seeks cases that can provide answers to research questions [34]. The sample is the strategic choice of the researcher and is based on the logic of the research [35].

The focus of this research was small enterprises from the information communication technology (ICT) sector. All three chosen firms were registered for computer programming, consultancy, and related activities. Data were collected through semi-structured interviews and discussions with the founders, who also held managerial positions at the selected firms. The interview questionnaire was based on the Business Model Canvas, which is a commonly used tool for presenting the business model of a firm. In addition to the conducted interviews, secondary data sources in the form of available financial statements of firms were also used. Table 2 shows the basic information about the interviewees.

Table 2. Overview or the case study interviews.

\begin{tabular}{cccc}
\hline Case 1 & Case 2 & Case 3 \\
\hline Position & Founder/manager & Founder/manager & Founder/manager \\
\hline Education & $\begin{array}{c}\text { Higher education } \\
\text { (Business) }\end{array}$ & $\begin{array}{c}\text { Higher education } \\
\text { (Mathematics) }\end{array}$ & $\begin{array}{c}\text { Higher education } \\
\text { (Business) }\end{array}$ \\
\hline Age & 63 & 47 & 41 \\
\hline Prior experience & Software developer & $\begin{array}{c}\text { Computer science } \\
\text { teacher, software } \\
\text { developer }\end{array}$ & $\begin{array}{c}\text { Co-owner of web design } \\
\text { company, freelancer }\end{array}$ \\
\hline Founding year & 1990 & 2003 & 2008 \\
\hline Net profit (2018) & 45 & 50 & 47 \\
\hline
\end{tabular}

The ICT sector was chosen because of its undeniable importance, both for the development of society as a whole and for the economy of each country including Croatia. This is a sector of great 
significance because of the increasing importance of information technologies in everyday life and everyday business. The ICT industry is an important contributor to the growth of every economy and is an important piece of the competitiveness of each country [36]. Technology can be seen as one of the main drivers of the innovations, which are crucial for further development. Firms with a core business in the ICT industry create growth, generate new employment, and provide products and services for all stakeholders. The ICT sector in Croatia has shown continuous growth in the last decade and an increase in export, new ventures, and new employments. To conclude, the importance of the ICT industry for a country's economy exceeds its contribution to the country's gross product and the number of workers it employs, because in addition, the ICT sector is an infrastructural activity and has a major impact on the country's competitiveness [37]. It is an extremely competitive industry in which it is quite difficult to achieve a sustainable competitive advantage. The three analyzed firms have been operating in the sector for many years and continuously achieve excellent results and successfully survive in a very competitive market. The aim of these analyses was to compare the business models of these firms and derive conclusions about their similarities and differences.

\subsection{Defining the Framework}

After conducting interviews and collecting data, each case was analyzed individually. Based on the conducted analysis and the conclusions, it will be possible to discuss the importance of the business model for creating a sustainable competitive advantage. Business Model Canvas was used as a tool for analyzing and presenting the chosen firms. It is a well-known and highly used tool due to its clarity and logic. According to scientists, consultants, and entrepreneurs, Business Model Canvas provides better development of the strategies, creates a shared language, and contributes to the development of higher quality ideas. Additionally, Business Model Canvas is used for the development of new business, new products, or services within the existing business model, strategic reorientation, and innovations [38]. Analysis and comparison of these business models were done using the business model assessment framework (Table 3), which provides a scale for evaluating each of the nine components of the Business Model Canvas [39].

Table 3. Framework for characterization of the business model components.

\begin{tabular}{|c|c|c|c|c|c|}
\hline \multirow{2}{*}{$\begin{array}{l}\text { Components } \\
\text { of Business } \\
\text { Model Canvas }\end{array}$} & \multicolumn{5}{|c|}{ Scale of Characteristics } \\
\hline & Low (1) & & Middle (2-4) & & High (5) \\
\hline $\begin{array}{c}\text { VP-Value } \\
\text { Propositions }\end{array}$ & Standardized & Professional & Semi-customized & Customized & Fully customized \\
\hline $\begin{array}{l}\text { CS-Customer } \\
\text { Segments }\end{array}$ & Local & Regional & National & $\begin{array}{l}\text { International } \\
\text { customers in } \\
\text { Croatia }\end{array}$ & $\begin{array}{c}\text { International } \\
\text { customers abroad }\end{array}$ \\
\hline CH-Channels & $\begin{array}{l}\text { Direct sale } \\
\text { channel }\end{array}$ & Web sales & $\begin{array}{c}\text { One } \\
\text { intermediary }\end{array}$ & $\begin{array}{l}\text { Partners and } \\
\text { intermediary }\end{array}$ & $\begin{array}{l}\text { Two or more } \\
\text { intermediaries }\end{array}$ \\
\hline $\begin{array}{l}\text { CR-Customer } \\
\text { Relationships }\end{array}$ & Depersonalized & Automated & Semi-personalized & Personalized & $\begin{array}{l}\text { Distinctively } \\
\text { personalized }\end{array}$ \\
\hline $\begin{array}{l}\text { KA-Key } \\
\text { Activities }\end{array}$ & $\begin{array}{l}\text { Distinctive } \\
\text { activity in } \\
\text { narrow domain }\end{array}$ & & $\begin{array}{c}\text { Few distinctive } \\
\text { activities }\end{array}$ & & $\begin{array}{c}\text { Integrate broad scope } \\
\text { of distinctive } \\
\text { activities }\end{array}$ \\
\hline $\begin{array}{l}\text { KR-Key } \\
\text { resources }\end{array}$ & Financial & Physical & Human & Intellectual & Organizational \\
\hline $\begin{array}{c}\text { KP-Key } \\
\text { partnerships }\end{array}$ & $\begin{array}{c}\text { Occasional } \\
\text { subcontractors }\end{array}$ & $\begin{array}{c}\text { Few contractual } \\
\text { partners }\end{array}$ & $\begin{array}{l}\text { Long-term } \\
\text { partners }\end{array}$ & $\begin{array}{l}\text { Formalized and } \\
\text { unformalized } \\
\text { agreements }\end{array}$ & $\begin{array}{c}\text { Complex set or } \\
\text { arrangements, open } \\
\text { network }\end{array}$ \\
\hline
\end{tabular}


Table 3. Cont.

\begin{tabular}{|c|c|c|c|c|c|}
\hline \multirow{2}{*}{$\begin{array}{c}\text { Components } \\
\text { of Business } \\
\text { Model Canvas }\end{array}$} & \multicolumn{5}{|c|}{ Scale of Characteristics } \\
\hline & Low (1) & & Middle (2-4) & & High (5) \\
\hline $\begin{array}{l}\text { CS-Cost } \\
\text { structure }\end{array}$ & $\begin{array}{l}\text { Fixed costs } \\
\text { driven }\end{array}$ & $\begin{array}{l}\text { Variable cost } \\
\text { driven }\end{array}$ & $\begin{array}{c}\text { Economics of } \\
\text { scale }\end{array}$ & Economies of scope & $\begin{array}{c}\text { 'Creative design } \\
\text { process' and value } \\
\text { driven }\end{array}$ \\
\hline $\begin{array}{l}\text { RS-Revenue } \\
\text { streams }\end{array}$ & $\begin{array}{c}\text { Transactional } \\
\text { service sale }\end{array}$ & $\begin{array}{l}\text { + "pay per } \\
\text { use/renting" }\end{array}$ & $\begin{array}{l}+ \text { fee, in advance, } \\
\text { premium access }\end{array}$ & $\begin{array}{c}\text { + after sale service } \\
\text { or complementary } \\
\text { products }\end{array}$ & $\begin{array}{l}\text { +third party } \\
\text { supported (bonus, } \\
\text { bartering) }\end{array}$ \\
\hline
\end{tabular}

Source: Pfeifer, S., Oberman Peterka, S., Stanić, M. Business models of micro businesses: Empirical evidence from creative industries. Management: Journal of Contemporary Management Issues, 2017, 22.Special Issue, 1-19 [39].

This framework was developed by Pfeifer et al. (2017) [39] for the purpose of assessing business models of service-centered businesses. A scale of 1 to 5 does not indicate a better or worse rating of an individual component, but an evaluation of its complexity and distinctiveness. The suggested framework includes a scale of characteristics that explains the performance of a business in terms of business model components. The logic behind the framework, and interpretation of the components is as follows:

- Value proposition: degree of customization of the service (from standardized offer to fully customized);

- Customer segments: complexity of the market according to the location of the customers (from local market to a higher degree of internationalization);

- Channels: complexity according to the number of steps to deliver service from the firm to the customer (from direct sale to several intermediaries);

- Customer relationships: degree of personalization for each customer (from no personalization to distinctively personalized approach to customers);

- Key activities: scope of the activities (from one basic activity to broad scope of activities of the business);

- Key resources: complexity of the main resources (from financial resources as the elementary resource to organizational as composite resource);

- Key partnerships: degree of reliance on the partners outside of the firm (from occasional collaboration to complex networks of partnerships and open networks);

- Cost structure: complexity of the business costs (from fixed costs to more complex structures); and

- Revenue streams: complexity of business revenues (from simple service sale to additional services).

Valuation of the components of the business model of selected firms was conducted based on the data collected during the interviews and additional secondary data (business websites, professional financial database, relevant news).

\section{Creating a Successful Business Model in the ICT Industry-Case Study}

The ICT industry is an extremely competitive industry and it is difficult for firms to achieve sustainable competitive advantage. A firm's business model has to be designed and implemented in such a way that it meets the customers' needs, while at the same time, allows achieving sustainable profit for the firm. Although there is no general business model that can guarantee success, a good business model provides a competitive advantage and is the foundation for market success. A good business model captures the core logic and dominant strategy of a venture, reflecting the entrepreneur's creativity in addressing critical questions [1]. 


\subsection{Case 1 Overview}

Case 1 was a small firm founded in 1991. The firm has four owners, and in 2018, they employed 45 people. It was founded by four co-owners, who had previously worked together for many years. All four owners had equal shares in the firm, all four of them worked in the firm, and each was in charge of a different segment of the business. Figure 1 shows the Business Model Canvas of the firm. Since its founding, the firm has been involved in various activities in the ICT industry, but software development has always been the fundamental idea. The firm started with hardware sales, school of informatics, computer repair service, however, the firm today focuses on its main product, a business application for the integration of business processes and an improvement in business operations. Their product is the dominant EAS (Enterprise Application Suite) in the Croatian market, where they have numerous customer references. The firm has a customized value proposition for each customer operating on the Croatian market (with the possibility of continuing cooperation with existing clients who decide to expand internationally). The firm uses its website as the main sales channel, without intermediaries and partners. Customer relations are extremely important, and the firm has a personalized approach for each client. The firm is focused on several specific activities. It is quite clear that intellectual capital, which derives from employee knowledge, is crucial for the firm, and since employee costs make up the largest part of the cost structure, this means that the firm has a high share of fixed costs. The firm wants to build independence, and does not have partners. The revenue streams of the firm consist of the sales of services and various after-sale and complementary activities (implementation, consulting, and support). The firm is aware of its strategic position - its strengths and weaknesses-as well as the opportunities and threats in the environment. They are aware of their position in relation to the competition, which they regularly monitor.

\begin{tabular}{|c|c|c|c|c|c|}
\hline \multirow[t]{2}{*}{$\begin{array}{l}\text { - } \text { Microsoft } \\
\text { Gold partner } \\
\text { There are no } \\
\text { significant } \\
\text { partnerships - } \\
\text { focus on } \\
\text { independence }\end{array}$} & $\begin{array}{l}\text { Key activities } \\
\begin{array}{ll}\text { - } & \text { Software } \\
& \text { development } \\
\text { - } & \text { Consulting } \\
\text { - } & \text { Implementati } \\
& \text { on } \\
\text { - } & \text { Support }\end{array}\end{array}$ & \multirow{2}{*}{\multicolumn{2}{|c|}{$\begin{array}{l}\text { Value propositions } \\
\begin{array}{l}\text { - Comprehensive } \\
\text { business } \\
\text { application } \\
\text { Expertise, } \\
\text { flexibility and } \\
\text { configurability } \\
\text { - Specialization } \\
\text { for specific } \\
\text { industries } \\
\text { Vertical } \\
\text { solutions } \\
\text { Ongoing } \\
\text { support and } \\
\text { consulting }\end{array}\end{array}$}} & 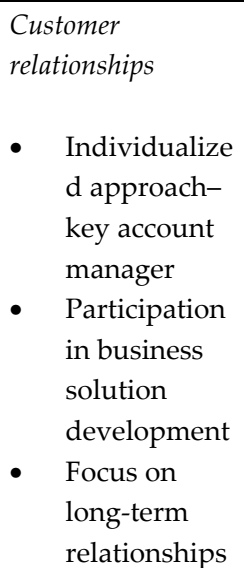 & \multirow[t]{2}{*}{$\begin{array}{l}\text { Customer segments } \\
\begin{array}{l}\text { - Business to } \\
\text { business (B2B) } \\
\text { - Croatian } \\
\text { market } \\
\text { - Industries: } \\
\text { manufacturin } \\
\text { g, wholesale } \\
\text { and retail, } \\
\text { agriculture, } \\
\text { forestry and } \\
\text { fishing }\end{array}\end{array}$} \\
\hline & $\begin{array}{l}\text { Key resources } \\
\text { - } \quad \text { Employees } \\
\text { - } \quad \text { Microsoft } \\
\text { technologies }\end{array}$ & & & $\begin{array}{l}\text { Channels } \\
\text { - Website } \\
\text { - } \quad \text { Facebook } \\
\text { - } \quad \text { Google } \\
\quad \text { AdWords }\end{array}$ & \\
\hline \multicolumn{3}{|c|}{$\begin{array}{l}\text { Cost structure } \\
\text { - } 60.7 \text { percent of total expenditures are fixed } \\
\text { costs (employee costs - salaries, training, etc.) }\end{array}$} & \multicolumn{3}{|c|}{ 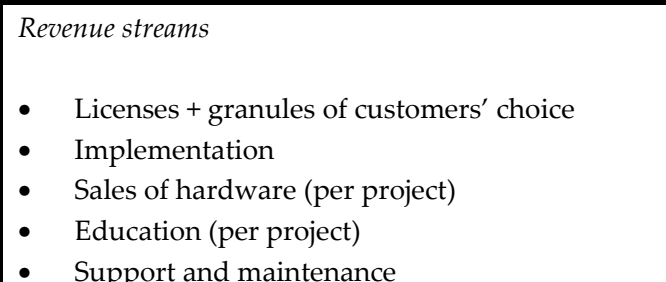 } \\
\hline
\end{tabular}

Figure 1. Case 1: Business Model Canvas.

Figure 2 shows the evaluation of components of the business model of Case 1. 


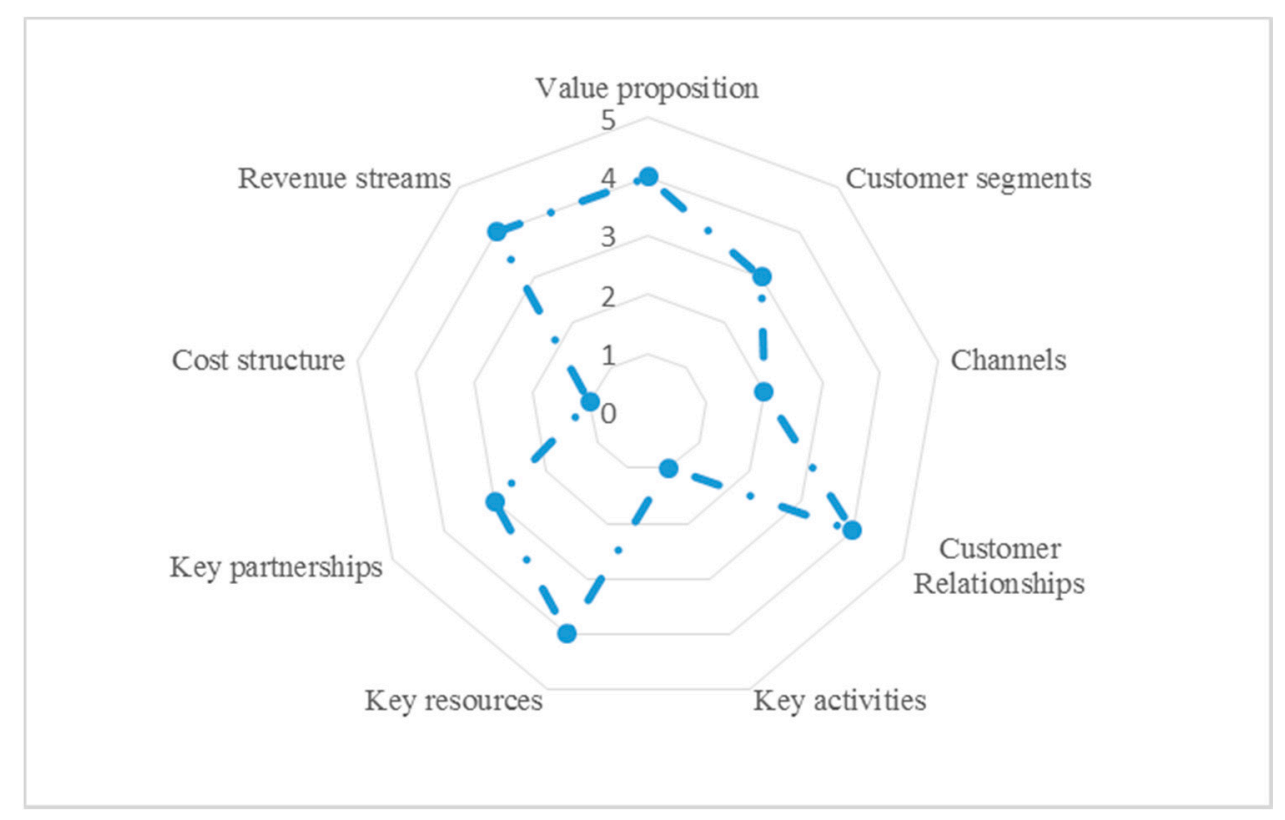

Figure 2. Key components of the Case 1 business model.

Case 1 builds its competitive advantage based on a personalized approach and value proposition, with the help of the knowledge and experience of its employees, without whom this would not be possible. Ongoing customer support and the creation of long-term relationships are an important foundation for building a competitive advantage as well as a source of income.

\subsection{Case 2 Overview}

Case 2 was founded in 2003, by three co-owners, and by 2018, it had grown and employed 50 people. Case 2 is developing its business in three directions: sales of finished products (applications for high-end industries), outsourcing; and solutions for other software firms. Their Business Model Canvas is shown in Figure 3. The firm has a fully customized value proposition for its customers, especially in the case of outsourcing. Customers are from all around the world, and the firm does business with clients in a large number of countries. Their website is the main sales channel, but sales are also made through intermediaries/partners in certain countries, with which the firm has formalized and non-formalized relations. This firm performs several specific activities, which is reflected in their value proposition. However, what is common for all activities is their continuous and fast client support, and urgent problem solving. The most important resource of this firm are its employees, who always use cutting edge technologies, and their knowledge becomes the intellectual capital of the firm. With regard to employees as the key resource, fixed costs have the highest share in the firm's cost structure. Revenue streams come from the sales of products and services, and after-sale support. It is evident that the firm knows its strengths and weaknesses, knows its competition, and what are the relationships between companies in the market. The owners are aware that they have to be competitive in terms of everything they offer, so they observe the competition, their offering, prices, and the way they provide customer support. Trends in technology development are crucial, as they strive to be a firm that builds its business on the latest technologies. 


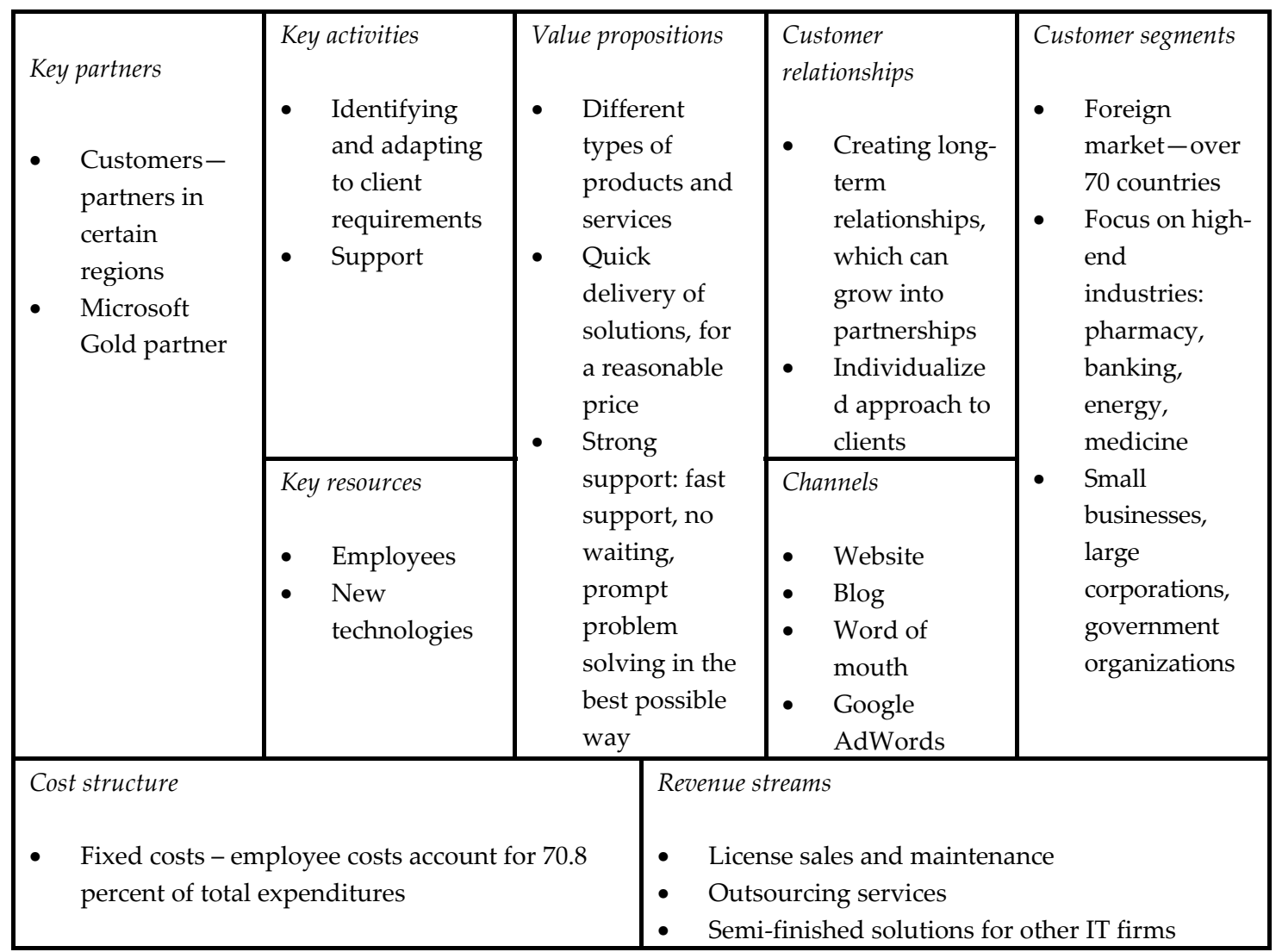

Figure 3. Case 2: Business Model Canvas.

Using the framework for evaluating components of the business model, an analysis of Case 2's business model was conducted (Figure 4).

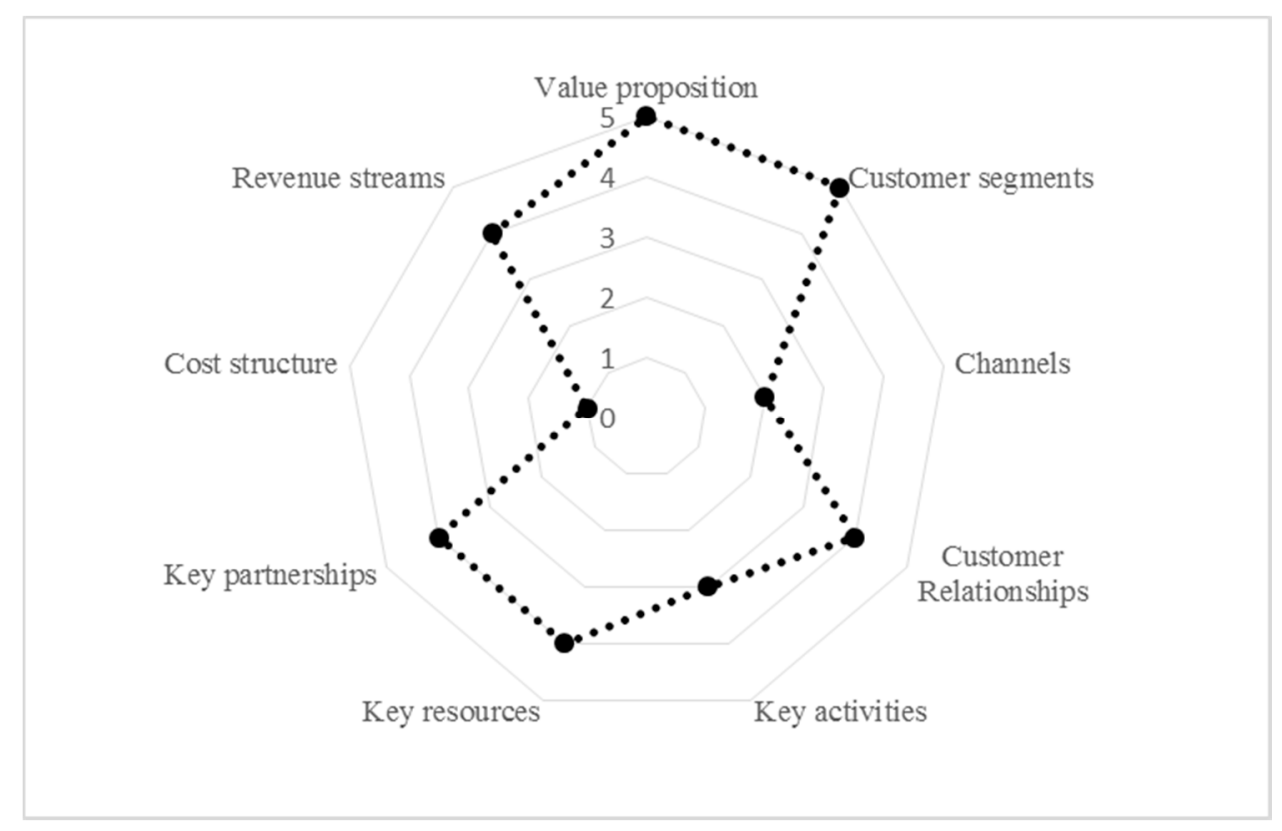

Figure 4. Key components of the Case 2 business model.

Competitive advantage is achieved through a rich value proposition, with a focus on continuous and timely support. Employee knowledge and the use of the latest technologies provide the foundation 
for creating value proposition and providing support. Additionally, the presence of partners in important markets facilitate access to those markets and supports the firm toward growth.

\subsection{Case 3 Overview}

Case 3,was founded in 2008 by one owner, while in 2018, it had four co-owners and employed 47 people. Since the very beginning, the firm decided to specialize in one type of service: the development of web shops on the Magento platform. Thus, the main activity of the firm is the development of solutions for online sales, from the idea and concept to launch and maintenance of the web shop. This includes designing, building, and optimizing an existing online store, introducing another platform, or creating an online store from scratch. The solutions they provide do not consist only of the online store, but often include various integrations with the client's existing systems such as Enterprise Resource Planning (ERP), various marketing channels, paying devices, delivery calculations, and synchronization with courier services. The Business Model Canvas of the firm is show in Figure 5. The firm offers a fully customized value proposition for customers operating on the global market. The sales are direct, and without intermediaries and partners in the process. Customer relationships are fully customized, a relationship is built with each customer, and the firm often becomes an important partner for the development of the client's business. The firm is specialized and engages in distinctive activities within a narrow domain, namely the development of online stores, on a specific platform. Employees are the firm's main resource and due to their importance, they are the firm's biggest expense. The firm's revenue comes from the sales of services and after-sale and complementary activities. All components of the business are continuously analyzed and there is a strong focus on continuous improvement. They are aware of competition at the local and global level, and everyone in the firm is in charge of monitoring trends.

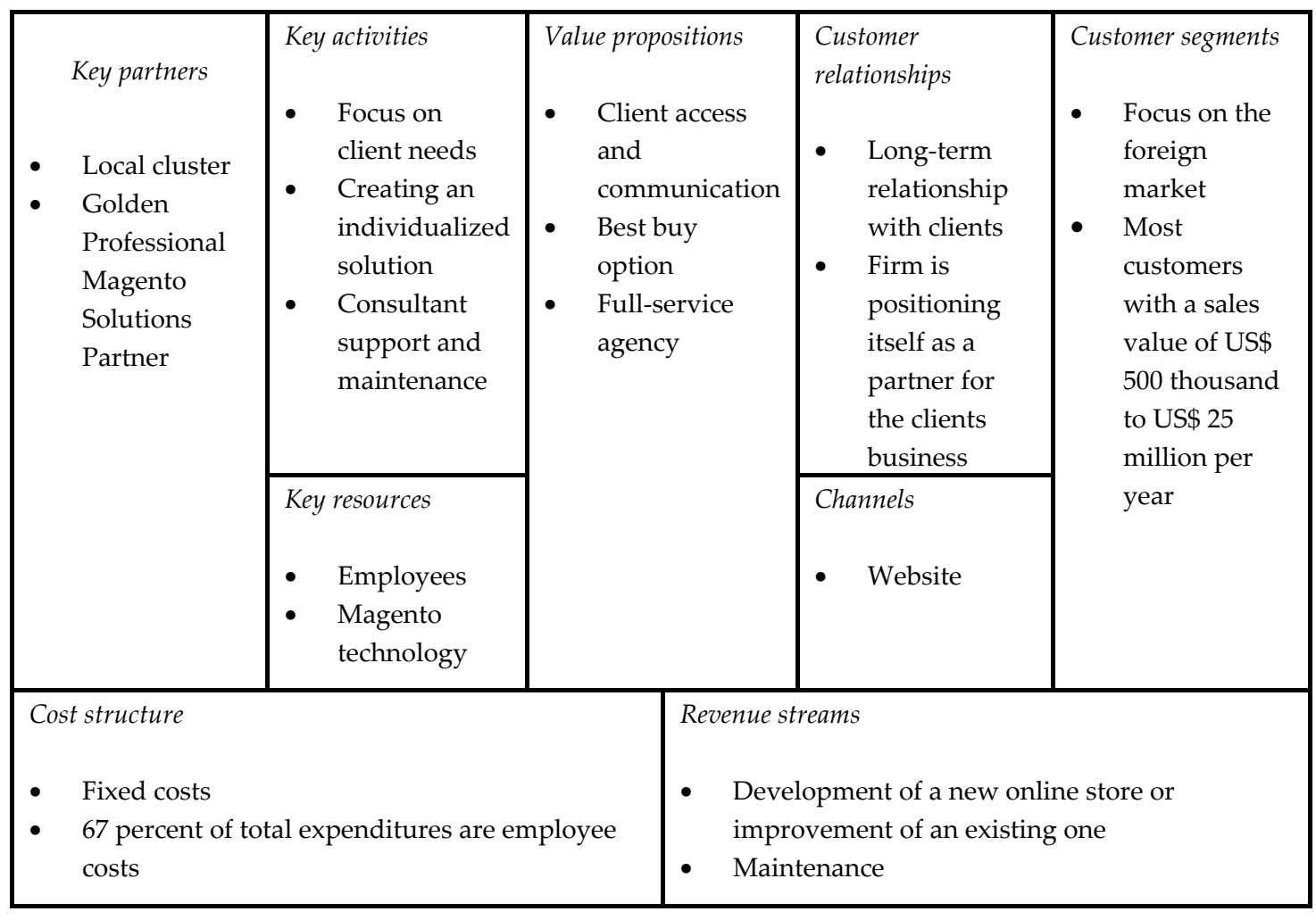

Figure 5. Case 3: Business Model Canvas.

Analysis of the components is shown in Figure 6. 


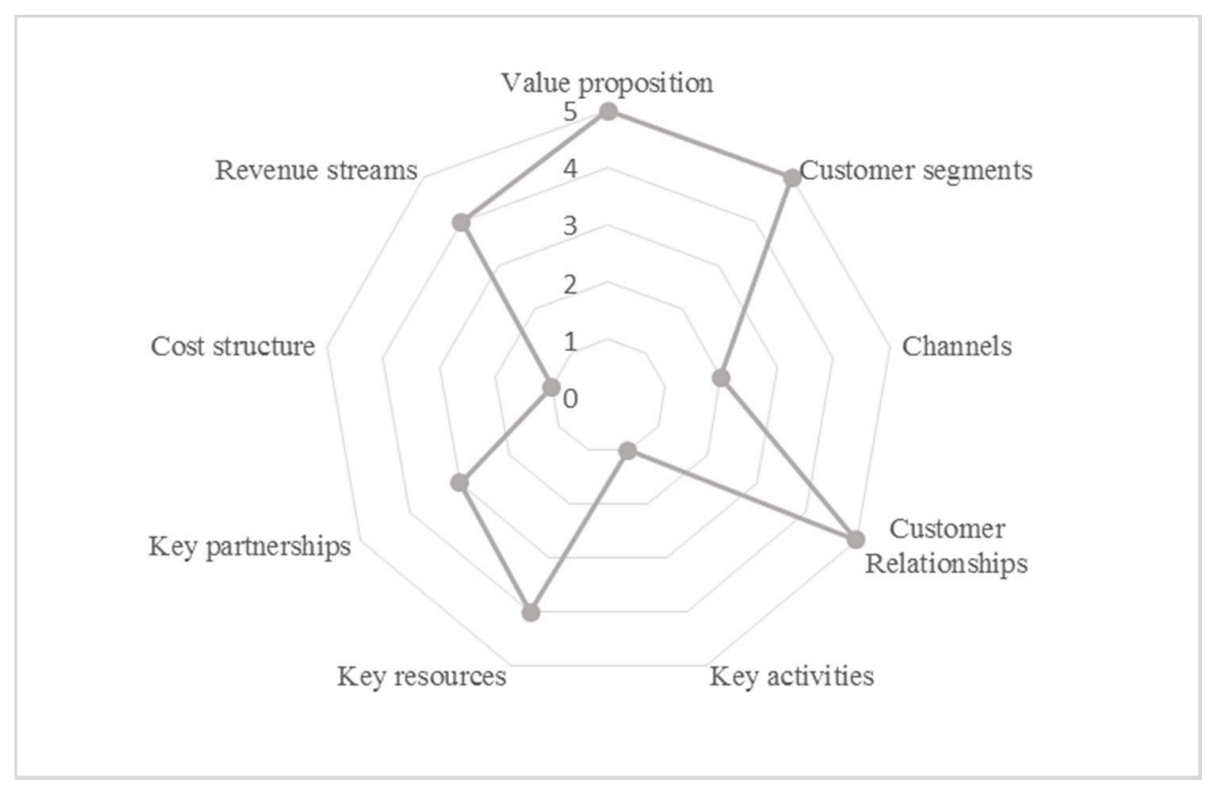

Figure 6. Key components of the Case 3 business model.

Case 3 builds their competitive advantage on a narrow specialization of their offering of a specific service, performed using a specific technology. The firm's employees, who are certified experts in the technologies used by the firm, are an important foundation for building the offering, and because of that, they have become recognizable both in Croatia and worldwide.

\section{Discussion}

The business models of Case 1, Case 2, and Case 3 were analyzed using the business model assessment framework [39]. A comparative overview of the analyzed business models clearly showed the similarities and differences between firms, and was the basis for conclusions about the business model of small enterprises in the ICT sector (Figure 7).

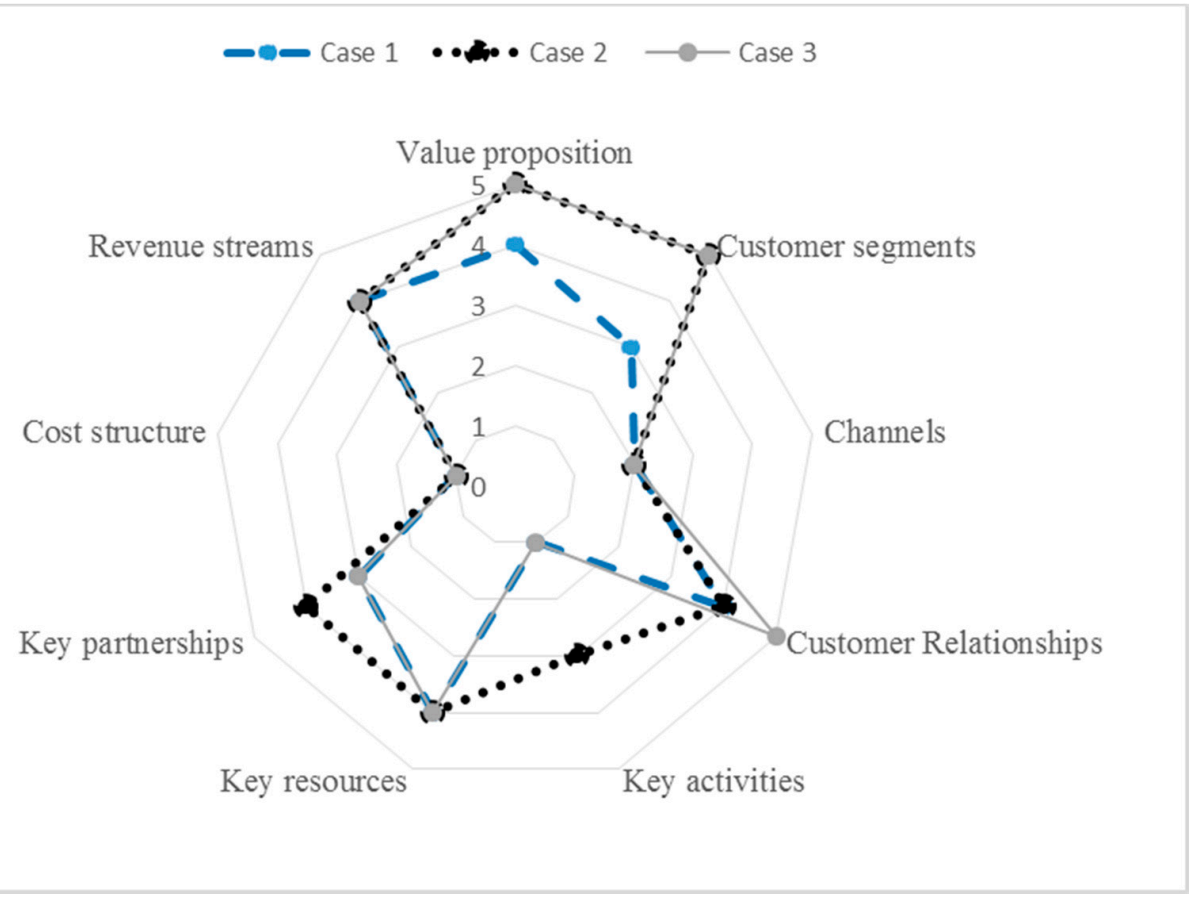

Figure 7. Comparison of components of the Business Model Canvas of the analyzed firms. 
The analyzed firms had overlaps in the following components of the Business Model Canvas:

- channels,

- key resources,

- cost structure, and

- revenue streams.

All analyzed cases used the firm's website as the main channel of communication with customers and as the main sales channel. In all analyzed firms, employee costs accounted for the highest and most significant share in costs. Such a cost structure is expected given that employees and their knowledge were recognized as a key resource in all firms. Although employees were a key resource for all three firms, two of the firms based their recognizability also on the technologies they used. Highly specialized Case 3 used Magento technology to create e-commerce solutions. Case 2 utilized a wide range of cutting edge technologies to develop its solutions. Case 1 emphasized that although their product is currently based on Microsoft technologies, they did not want to depend on any technology, and were considering different what-if scenarios. All three firms had the same approach to generating revenue, which was based on the sales of products/services and on after-sale activities and complementary products (in the form of support and additional services). Case 1 and Case 2 had license sales as a source of income; Case 2 and Case 3 overlapped in providing outsourcing services, and the most significant part of income for all three firms came from support and maintenance.

The analyzed firms differed to some extent in the following components of the business model:

- value propositions,

- customer segments,

- customer relationships,

- $\quad$ key activities, and

- $\quad$ key partnerships.

The products and services that the firms offered were different, and thus their value propositions and customer segments also differed. Case 1 showed a strong determination to operate exclusively on the domestic market. Case 2 and Case 3 explained that the majority of their revenue came from foreign markets, but their target industries were quite different, as were their services. All three firms wanted to develop long-term relationships with customers and develop an individualized approach, but Case 3 had a fully customized approach to each customer. Case 1 and Case 3 were engaged in a distinctive activity in a narrow domain, while Case 2 had several distinctive activities. Differences also occurred in the key partnerships component because Case 1 and Case 3 had long-term partnerships, which were important because of the technologies they used (Microsoft Gold Partner and Professional Magento Solutions Partner, respectively). Case 2 developed sales partnerships and had formalized and non-formalized contracts with partners in that domain.

These analyses showed the similarities and differences of the business model of small firms in the ICT industry. To sum up, all three firms built their competitive advantage in carefully selected markets, with a well-thought and elaborated value proposition. What they had in common was the fact that they had all managed to organize their business model in such a manner that, through the combination of all components, they were achieving a distinctive and sustainable competitive advantage that allowed them to accomplish exceptional business results, and thus further growth and development, which all three firms expressed as a plan for the future.

\section{Conclusions}

Doing business in today's market is characterized by strong competition, which means that finding and maintaining a competitive advantage is a difficult challenge for any firm. The business model is the basis for defining the competitive advantage of each venture, because it helps in understanding and defining its specificity. This paper presented and analyzed the business models of three small firms 
in the ICT sector. These were successfully fighting competition and achieving exceptional financial results and growth. The study tried to provide the answer about specific and important components of the business model, which could help in creating and sustaining a competitive advantage.

What can be concluded from the case study analysis is that all three firms were aware of the specifics and trends of their industry. Although at first glance it seemed that the business models of Case 1, Case 2, and Case 3 were completely different, using the business model assessment framework, it was evident that the business models were very similar and that they coincided in key elements. Due to the specifics of the industry, the three observed firms had expected overlaps in certain components of the business model such as key resources and cost structure. The specificity of this industry constantly emphasized the importance of employees, who are in fact the bearers of the overall business and success of the firm, and their importance was reflected in the firm's cost structure. Furthermore, all firms had direct contact with their customers, with whom they had personalized and long-term relationships, because they provided services that required constant support and improvement due to continuous changes coming from the environment. However, the analyzed firms were building their competitive advantage through a different combination of value propositions and customer segments, with a set of key activities and partnerships that has allowed them to gain market position, build visibility, and achieve good results for many years.

Based on these conclusions, this study can provide a theoretical and managerial contribution. Theoretical contributions can be found in using and testing the framework for the characterization of the business model components, developed for service industries. Additionally, this study identified several crucial components of the sustainable business model of small firms in the ICT industry (key resources, channels, revenue stream, and cost structure) that are common for those firms. Consequentially, firms need to focus on differentiating the rest of the elements of the business model in order to ensure their sustainability. Managerial contributions are relevant for owners of SMEs and managers in the ICT industry. It is important to raise awareness of the constant evaluation of the business model of the firm in order to be able to anticipate and react to industry trends. Business Model Canvas can give a clear understanding of a firm's business and competitive advantage. Analysis of these successful cases can help other firms to better understand their own business models, and to combine elements in such a manner that ensures differentiation and sustainability. The SME sector is a crucial part of every economy, and providing applicable tools that can help firms in that sector to deal with the uncertainty and complexity of everyday business could assist in their growth and development.

Limitations of this study are related to the specific country context, as the selected cases were firms in Croatia. Surely, focus on other countries might give diverse results if a similar study is to be conducted due to differences in the entrepreneurial ecosystem. Additionally, the qualitative study does not provide a broader generalization of the results, therefore, this study could be the basis for conducting qualitative research in defined industries to gain insights for further development of the SME sector within the ICT industry.

Finally, this study provides some new research ideas. It would be interesting to conduct and analyze business models in other sub-industries of the ICT sector, given that the three observed firms were part of the computer programming, consultancy, and related activities. In addition, it is possible to expand the research to other industries and make a comparison of business models in selected industries. Given that the framework for the evaluation of business model components was used in this paper, it is possible to conduct business model analysis using another measuring instrument and make a comparison of the obtained results with the results of this paper. A more complex research could be done in the form of a better understanding of thee interactions between the business model components or by developing a new instrument to measure the key success factors of a business model.

Author Contributions: Conceptualization, T.K. and S.O.P.; Formal analysis, T.K.; Investigation, T.K.; Methodology, T.K. and S.O.P.; Resources, S.O.P.; Supervision, S.O.P.; Validation, S.O.P.; Visualization, T.K.; Writing-original draft, T.K.; Writing-review \& editing, T.K. and S.O.P. All authors have read and agreed to the published version of the manuscript. 
Funding: This research received no external funding.

Conflicts of Interest: The authors declare no conflict of interest.

\section{References}

1. Morris, M.; Schindehutte, M.; Richardson, J.; Allen, J. Is the business model a useful strategic concept? Conceptual, theoretical, and empirical insights. J. Small Bus. Strategy 2006, 17, 27-50.

2. Osterwalder, A.; Pigneur, Y. Stvaranje Poslownih Modela; Školska knjiga: Zagreb, Croatia, 2014.

3. Morris, M.; Schindehutte, M.; Allen, J. The entrepreneur's business model: Toward a unified perspective. J. Bus Res. 2005, 58, 726-735. [CrossRef]

4. Zott, C.; Amit, R.; Massa, L. The business model: Recent developments and future research. J. Manag. 2011, 37, 1019-1042.

5. Wirtz, B.W.; Pistoia, A.; Ullrich, S.; Göttel, V. Business models: Origin, development and future research perspectives. Long Range Plan. 2016, 49, 36-54. [CrossRef]

6. Saleem, F.; Fakieh, B. Enterprise Architecture and Organizational Benefits: A Case study. Sustainability 2020, 12, 8237. [CrossRef]

7. Mendelson, H. Organizational architecture and success in the information technology industry. Manag. Sci. 2000, 46, 513-529. [CrossRef]

8. Baden-Fuller, C.; Morgan, M.S. Business models as models. Long Range Plan. 2010, 43, 156-171. [CrossRef]

9. European Commision. Annual Report on European SMEs 2016/2017. Available online: https://op.europa. eu/en/publication-detail/-/publication/0b7b64b6-ca80-11e7-8e69-01aa75ed71a1/language-en/format-PDF (accessed on 29 October 2020).

10. Barringer, B.R.; Ireland, R.D. Poduzetništvo-Uspješno Pokretanje novih Poduhvata, 3rd ed.; OFF-SET: Tuzla, Bosnia and Herzegovina, 2010.

11. Teece, D.J. Business models, business strategy and innovation. Long Range Plan. 2010, 43, 172-194. [CrossRef]

12. Andreini, D.; Bettinelli, C. Business model innovation: From systematic literature review to future research directions. J. Manag. Gov. 2017, 21, 785-792.

13. Johnson, M.W.; Christensen, C.M.; Kagermann, H. Reinventing your business model. Harv. Bus Rev. 2008, 86, 57-68.

14. Shi, Y.; Manning, T. Understanding business models and business model risks. J. Priv. Equity 2009, 12, 49-59. [CrossRef]

15. Vives, L.; Svejenova, S. To, from and beyond the margins: Business models: Towards an integrative framework. Manag. Res. J. Iberoam. Acad. Manag. 2011, 9, 230-242. [CrossRef]

16. Giesen, E.; Riddleberger, E.; Christner, R.; Bell, R. When and how to innovate your business model. Strateg. Lead. 2010, 38, 17-26. [CrossRef]

17. Mitchell, D.; Coles, C. The ultimate competitive advantage of continuing business model innovation. J. Bus. Strateg. 2003, 24, 15-21. [CrossRef]

18. Malhotra, Y. Knowledge management and new organization forms: A framework for business model innovation. Inf. Resour. Manag. J. 2000, 13, 5-14. [CrossRef]

19. Wirtz, B.W.; Gottel, V.; Daiser, P. Business model innovation: Development, concept and future research Directions. J. Bus. Models 2016, 4, 1-28.

20. Dru, J.M. Disruption: Overturning Conventions and Shaking up the Marketplace; John Wiley \& Sons: San Francisco, CA, USA, 1996.

21. Keiningham, T.; Aksoy, L.; Bruce, H.L.; Cadet, F.; Clennell, N.; Hodgkinson, I.R.; Kearney, T. Customer experience driven business model innovation. J. Bus. Res. 2020, 116, 431-440. [CrossRef]

22. Bocken, N.; Snihur, Y. Lean startup and the business model: Experimenting for novelty and impact. Long Range Plan. 2020, 53, 1019-1053. [CrossRef]

23. Evans, S.; Vladimirova, D.; Holgado, M.; Van Fossen, K.; Yang, M.; Silva, E.A.; Barlow, C.Y. Business model innovation for sustainability: Towards a unified perspective for creation of sustainable business models. Bus. Strateg. Environ. 2017, 26, 597-608. [CrossRef]

24. Bocken, N.M.P.; Schuit, C.S.C.; Kraaijenhagen, C. Experimenting with a circular business model: Lessons from eight cases. Environ. Innov. Soc. Transit. 2018, 28, 79-95. [CrossRef] 
25. Pieroni, M.P.; McAloone, T.C.; Pigosso, D.C. Business model innovation for circular economy and sustainability: A review of approaches. J. Clean Prod. 2019, 215, 198-216. [CrossRef]

26. Massa, L.; Tucci, C.L.; Afuah, A. A critical assessment of business model research. Acad. Manag. Ann. 2017, 11, 73-104. [CrossRef]

27. Baden-Fuller, C.; Mangematin, V. Business models: A challenging agenda. Strateg. Organ. 2013, 11, $418-427$. [CrossRef]

28. Porter, M.E. Competitive Advantage: Creating and Sustaining Superior Performance; The Free Press: New York, NY, USA, 1998.

29. Halmi, A. Strategije Kvalitativnih Istraživanja u Primijenjenim Društvenim Znanostima; Naklada Slap: Jastrebarsko, Croatia, 2005.

30. Eriksson, P.; Kovalainen, A. Qualitative Methods in Business Research: A Practical Guide to Social Research; Sage: London, UK, 2016.

31. Saunders, M.; Lewis, P.; Thornhill, A. Research Methods for Business Students, 8th ed.; Pearson: London, UK, 2019.

32. Spiers, L.W. Corporate Governance and its Contribution to Risk and Crisis Management in Small Companies. Ph.D. Thesis, Bournemouth University, Bournemouth, Dorset, UK, 2018.

33. Curtis, S.; Gesler, W.; Smith, G.; Washburn, S. Approaches to sampling and case selection in qualitative research: Examples in the geography of health. Soc. Sci. Med. 2000, 50, 1001-1014. [CrossRef]

34. Saunders, M.; Lewis, P.; Thornhill, A. Research Methods for Business Students; Pearson: Essex, UK, 2012.

35. Seawright, J.; Gerring, J. Case selection techniques in case study research: A menu of qualitative and quantitative options. Polit. Res. Q. 2008, 61, 294-308. [CrossRef]

36. Maryska, M.; Doucek, P.; Kunstova, R. The importance of ICT sector and ICT university education for the economic development. Procedia Soc. Behav. Sci. 2012, 55, 1060-1068. [CrossRef]

37. Žitnik, B. Hrvatska IT industrija 1995-2015-2025 nastajanje-stanje-budućnost. OpenInfoTrend. 2015. Available online: http://www.infotrend.hr/files/pdf/casopis/2015/200/InfoTrend-200-special.pdf (accessed on 29 October 2020).

38. Amarsy, N. Why and How Organizations Around the World Apply the Business Model Canvas. Available online: http://blog.strategyzer.com/posts/2015/2/9/why-and-how-organizations-around-the-world-applythe-business-model-canvas (accessed on 29 October 2020).

39. Pfeifer, S.; Oberman Peterka, S.; Stanić, M. Business models of micro businesses: Empirical evidence from creative industries. Manag. J. Contemp. Manag. Issues 2017, 22, 1-19.

Publisher's Note: MDPI stays neutral with regard to jurisdictional claims in published maps and institutional affiliations.

(C) 2020 by the authors. Licensee MDPI, Basel, Switzerland. This article is an open access article distributed under the terms and conditions of the Creative Commons Attribution (CC BY) license (http://creativecommons.org/licenses/by/4.0/). 